\title{
PERLINDUNGAN HUKUM ANAK JALANAN DALAM KONSEP HAM PASCA REFORMASI
}

\author{
Maemunah \\ Program Studi Pendidikan Pancasila dan Kewarganegaraan FKIP \\ Universitas Muhammadiyah Mataram \\ Lombok, NTB, Indonesia \\ Email :maemunabdullah@gmail.com
}

\begin{abstract}
Abstrak
Setiap anak secara kodrati memiliki harkat, martabat dan hak-hak sebagai manusia yang harus dijunjung tinggi oleh siapapun, namun pelanggaran HAM terhadap anak masih terjadi berupa anak diterlantarkan, anak diperkerjakan, anak meminta-minta dijalan, kekerasan fisik anak dan anak diperdagangkan. Tujuan penelitian ini adalah untuk menjelaskan perlindungan hukum anak jalanan dalam konsep HAM menurut UndangUndang Dasar Negara Republik Indonesia 1945 pasca reformasi. Metode penelitian menggunakan penelitian hukum normatif dengan pendekatan konseptual dan perundangundangan. Bahan kajian hukum menggunakan bahan hukum primer, sekunder dan hukum tersier melalui study literature. Alat analisis yang dipergunakan adalah interpretasi hukum. Hasil penelitian menunjukkan bahwa perlindungan hukum anak jalanan dalam konsep HAM menurut Undang-Undang Dasar Negara Republik Indonesia 1945 pasca reformasi adalah yang senantiasa menjunjung tinggi dan melindungi hak-hak anak jalanan sebagai manusia yang berharkat dan bermartabat. Pertama, street based, yakni model penanganan anak jalanan di tempat anak jalanan itu berasal atau tinggal kemudian para street educator datang kepada mereka berdialog mendampingi mereka bekerja, memahami dan menerima situasinya serta menempatkan diri sebagai teman. Kedua, centre based, yakni pendekatan dan penanganan anak jalanan dilembaga atau panti. Ketiga, community based yakni metode penanganan yang melibatkan seluruh potensi masyarakat terutama keluarga atau orang tua anak jalanan.
\end{abstract}

Kata kunci: perlindungan hukum; anak jalanan; hak asasi manusia

\begin{abstract}
Every child naturally has dignity, dignity, and rights that must be upheld by anyone, but human rights violations against children still occur in the form of abandoned children, children employed, children begging on the streets, physical abuse of children and children trafficked. The purpose of this study was to explain Legal protection of street children in the concept of human rights, according to the 1945 Constitution of the Republic of Indonesia post-reform. The research method uses normative legal research with conceptual and statutory approaches. Legal study materials use primary, secondary, and tertiary legal documents through literature studies. The analytical tool used is a legal interpretation. The results showed that the legal protection of street children in the concept of human rights according to the 1945 Constitution of the Republic of Indonesia post-reform is that which always upholds and protects the rights of street children as human beings who are dignified and dignified. First, street-based, namely the model of handling street children where street children come from or live then the street educators come to them in dialogue to accompany them to work, understand and accept the situation and place themselves as friends. Second, center-based, namely the approach and handling of street children in institutions or institutions. Third, community-based is a method of processing that involves all the potential of the community, especially families or parents of street children.
\end{abstract}

Keywords: protection, law, street-children, human rights, reform 


\section{$A$. PENDAHULUAN}

Anak jalanan pada dasarnya adalah anak-anak marginal di perkotaan yang mengalami proses dehumanisasi ${ }^{1}$. Mereka bukan saja harus mampu bertahan hidup dalam suasana kehidupan kota yang keras tidak bersahabat dan tidak kondusif bagi proses tumbuh kembang anak. Tetapi, lebih dari itu mereka juga cenderung dikucilkan masyarakat menjadi obyek pemerasan berbagai pihak sesama teman, preman atau oknum aparat, sasaran eksploitasi, korban pemerkosaan, dan segala bentuk penindasan lainnya. Untuk menangani permasalahan anak jalanan harus diakui bukanlah hal yang mudah. Selama ini berbagai upaya sebenarnya telah dilakukan, baik oleh LSM, pemerintah, organisasi profesi dan sosial maupun orang per-orang untuk membantu anak jalanan keluar atau paling tidak sedikit mengurangi penderitaan mereka. Namun karena semuanya dilakukan secara temporer, segmenter, dan terpisah pisah maka hasilnya pun menjadi kurang maksimal. Isu tentang perlindungan anak semakin memprihatinkan, sejalan dengan meningkatnya kasus tindak kekerasan, eksploitasi dan perdagangan anak. Khusus di NTB isu itu dikaitkan dengan jenis Penyandang Masalah Kesejahteraan Sosial (PMKS) anak seperti, anak telantar, anak jalanan, balita telantar dan balita status gizi buruk yang saat ini jumlahnya cukup tingggi²

Masalah anak jalan sebagian besar telah diteliti oleh berbagai perspektif, Sri Sutatiek membahas dalam rangka memberikan perlindungan dan kesejahteraan anak, Hakim Anak dalam persidangan belum berperan secara optimal, karena belum semua pihak yang diatur dalam undang-undang pengadilan anak dilibatkan. Hakim juga belum dapat berperan sebagai pengganti ibu dan ayah Anak Nakal. Buktinya pidana penjara mayoritas

${ }^{1}$ Tjandraningsih, I., Sasmito, W., Munthe, R., Sp, O., Simandjuntak, A., Tigor, A., ... \& Sudrajat, T. (1996). Dehumanisasi anak marjinal: berbagai pengalaman pemberdayaan. AKATIGA.

${ }^{2}$ Suradi. (2006). Perlindungan Anak Di Nusa Tenggara Barat. Sosio Konsepsia. Jurnal Penelitian dan Pengembangan Kesejahteraan Sosial. 11 (3), hlm 1-17. dijatuhkan kepada Anak Nakal di Indonesia. Padahal secara teoritik maupun praktek jenis pidana tersebut mempunyai kelemahan, terutama pada masa depan anak. Pertimbangan yuridis lebih dominan digunakan oleh Hakim Anak dalam menetukan putusan pengadilan ${ }^{3}$, Fanny Tanuwijaya membahas kemiskinan merupakan sebab utama diantara beberapa sebab adanya pekerja anak. Peraturan perundang-undangan belum mengakomodasi kemiskinan sebagai sebab utama adanya pekerja anak, sehingga perlindungan hukum untuk pekerja anak belum berorientasi pada pengentasan kemiskinan pekerja anak ${ }^{4}$, Abdul Rachmad Budiono membahas kemiskinan merupakan sebab utama diantara beberapa sebab adanya pekerja anak. Peraturan perundang-undangan belum mengakomodasi kemiskinan sebagai sebab utama adanya pekerja anak, sehingga perlindungan hukum untuk pekerja anak belum berorientasi pada pengentasan kemiskinan pekerja anak ${ }^{5}$.

Netti Endrawati menguraikan bahwa belum adanya peraturan perundangan yang mengatur tentang pekerja anak disektor informal,khususnya terkait dengan perlindungan hukumnya, juga disebabkan oleh faktor aparatur pemerintah sebagai pengawas ketenagakerjaan, terutama jumlahnya yang lebih sedikit dibandingkan dengan perusahaan yang harus diawasi, tidak jumlahnya yang lebih sedikit dibandingkan dengan perusahaan yang harus diawasi, tidak adanya pelaporan berkala dari perusahaan terhadap kondisi ketenagakerjaan diperusahaan, kurang terbukanya perusahaan terhadap kondisi ketenagakerjaan terutama apabila dilakukan sidak, serta kultur apabila dilakukan sidak, serta kultur budaya yang memandang bahkan anak yang bekerja

${ }^{3}$ Sri Sutatiek. (2007). Putusan pengadilan anak sebagai manifestasi perlindungan dan kesejahteraan anak di Indonesia, Progran Doktror Ilmu Hukum pada Universitas Brawijaya Malang.

${ }^{4}$ Fanny Tanuwijaya. (2009). Pembinaan Anak Di Lembaga Pemasyarakatan Anak Dalam Rangka Perlindungan Hak Anak Pidana, Progran Doktror Ilmu Hukum pada Universitas Brawijaya Malang.

${ }^{5}$ Abdul Rachmad Budiono. 2007. Perlindungan Hukum Untuk Pekerja Anak, Program Doktor pada Universitas Airlangga Surabaya. 
dipandang sebagai hal yang biasa sebagai bentuk sosialisasi dan wujud darma bakti pada orang tua. Masyarakat kurang peduli, terutama dalam menyikapi penggunaan pekerja anak oleh perusahaan. Selain itu, disebabkan pula oleh lemahnya koordinasi dan kerjasama antara instansi atau lembaga terkait dibidang ketenakerjaan, seperti Dinas Sosial, Pemerintah Daerah setempat dan dinas terkait lainnya ${ }^{6}$, A.A.A.Ngurah Tini Rusmini Gorda membahas penanggulangan pedofilia bukan hanya tugas penegak hukum semata tetapi juga membutuhkan pemberdayaan masyarakat secara optimal dengan meningkatkan pertahanan keluarga ${ }^{7}$.

Berdasarkan permasalahan yang begitu kompleks tentang anak jalanan maka akan lebik bijak yang merupakan sebuah langkah maju membuat suatu aturan yang spesifik tentang anak jalanan. Lagi pula, peraturan itu akan memiliki bobot fungsi untuk meminimalisir kesenjangan undang-undang dan menjaga harmonisasi pelaksanaan dari beberapa undang-undang yang menyangkut perlindungan anak pada umumnya yang mana tidak ada keseragaman dalam memberikan pengertian terhadap anak sehingga implementasi dilapangan menjadi sangat sulit untuk pelaksanaan perlindungan anak. Selain itu sampai sekarang belum ada Peraturan Pemerintah yang dikeluarkan sebagai pelaksanaan Undang-Undang Nomor 23 Tahun 2002 tentang Perlindungan Anak sebagai acuan pemerintah Daerah dapat membuat peraturan daerahnya yang sesuai dengan kultur daerah masing-masing karena tidak bisa dipungkiri ada nilai-nilai budaya tradisional dari tiap daerah yang mempengaruhi cara pandang dan pola asuh orangtua terhadap anak. Sehingga peraturan lebih sejalan dengan kondisi anak jalanan yang mempunyai masalah yang heterogen

${ }^{6}$ Netti Endrawati. (2007). Perlindungan hukum terhadap pekerja anak disektor informal (studi kasus di Kota Kediri), Universitas Undonesia.

${ }^{7}$ A.A.A.Ngurah Tini Rusmini Gorda. (2010). Kebijakan Formulasi Pedofilia dalam Melindungi Anak sebagai Korban, Program Doktor Ilmu Hukum pada Univesitas Brawijaya Malang. bagi setiap anak baik masalahan penyebab dan pendorong anak turun kejalan sebagai anak jalanan. Bila peraturan hukum cocok dengan permasalahan anak jalanan maka lebih bisa diterima dan dipatuhi.

Tujuan dalam artikel adalah untuk menjelaskan perlindungan hukum anak jalanan dalam konsep ham menurut UUD NRI 1945 pasca reformasi. Kontribusi dalam penelitian ini dapat memberikan konsep hukum dalam menangani pelanggaran HAM pada anak jalanan pasca reformasi. Selain itu, adanya perlindungan hukum anak jalanan dapat memberikan perlindungan yang hakiki dalam setiap kehidupannya dari Negara, dengan demikian hak tersebut menimbulkan suatu kewajiban yang harus dipenuhi oleh Negara melalui perangkatnya yang bernama pemerintah sehingga tercipta kehidupan berbangsa dan bernegara dengan baik yang dapat melindungi hak-hak asasi anak jalanan yang mencirminkan prinsip-prinsip hak asasi manusia.

Dari sudut pandang teori hukum, ilmu hukum dibedakan menjadi ilmu hukum normatif, dan ilmu hukum empiris. Pandangan positivistik melahirkan ilmu hukum empiris, sedangkan pandangan normatif melahirkan ilmu hukum normatif. Dengan demikian, kajian terhadap hukum dapat dilakukan secara normatif dan dapat pula dilakukan secara empiris yang masing-masing memiliki karakteristik dan metode yang berbeda ${ }^{8}$.

\section{B. METODE PENELITIAN}

Metode penelitian merupakan prosedur dan teknik untuk menjawab permasalahan penelitian, karena itu penggunaan metode penelitian senantiasa disesuaikan dengan kebutuhan penelitian. Berdasarkan pendapat di atas maka penelitian ini tergolong dalam jenis penelitian hukum normatif yakni penelitian yang mengkaji peraturan perundang-undangan dalam suatu tata hukum

${ }^{8}$ J.J.H. Bruggink, Rechts Reflectiec,Alih Bahasa Arif Sidharta. (1996). Refleksi Hukum. (Citra Adiya Bakti, Bandung. hlm. 189. 
yang koheren ${ }^{9}$. Dalam hal ini hukum sebagai norma positif yang berlaku pada suatu waktu tertentu dan diterbitkan sebagai produk suatu kekuasaan politik tertentu yang memiliki legitimasi.

Penedekatan penelitian ini menggunakan pendekatan perundang-undangan (statute approach). Pendekatan perundang-undangan (statute approach) yakni dengan mengkaji dan meneliti peraturan perundang-undangan dibidang perlindungan anak serta peraturan perundang-undangan lain yang berhubungan prinsip-prinsphakasasianak.Untukitupeneliti melihat hukum sebagai sistem tertutup yang mempunyai sifat-sifat comprehensive artinya norma-norma hukum yang ada didalamnya terkait antara satu dengan lain secara logis dan systematic bahwa disamping bertautan antara satu dengan lainnya, norma-norma hukum tersebut juga tersusun secara hierarkis ${ }^{10}$. Pendekatan konsep (conceptual approach) yaitu suatu pendekatan dengan memahami unsur-unsur abstrak yang ada dalam alam pikiran. Menurut Ayn Rand, secara filsafat konsep merupakan integrasi mental atas dua unit atau lebih yang diisolasikan menurut ciri khas dan yang disatukan dengan definisi yang khas ${ }^{11}$. Pendekatan konsep (conceptual approach) dalam penelitian ini dimaksudkan untuk mengkaji konsep yang berkaitan dengan perlindungan hukum bagi anak jalanan di Indonesia yang mencerminkan prinsip-prinsip hak asasi anak. Sumber bahan hukum digunakan yakni bahan hukum primer, sekunder dan bahan hukum tersier ${ }^{12}$. Bahan hukum primer (primary legal resourse) yakni bahan hukum yang mengikat yang diperoleh dari peraturan perundang-undangan yang berkaitan dengan perlindungan anak jalanan yakni Pasal 28A- 28J perubahan

${ }^{9}$ Soetandyo Wignjosoebroto. 1995. Sebuah Pengantar Ke Arah Perbincangan Tentang Pembinaan Penelitian Hukum Dalam PJP II. Jakarta. BPHN Departemen Kehakiman. hlm. 5 .

${ }^{10}$ Hartono, Sunaryati. (1994). Penelitian Hukum di Indonesia pada Akhir Abad ke-20. Alumni Bandung.

${ }^{11}$ Soekanto, Soerjono dan Purnadi Purbacaraka. (1993). Perihal Kaedah Hukum, Citra Adita Bakti Bandung.

${ }^{12}$ Soekanto, Soerjono dan Purnadi Purbacaraka.(1993). Perihal Kaedah Hukum. Citra Adita Bakti Bandung. kedua dan pasal 34 ayat $(1,2,3)$ Perubahan keempat Undang-Undang Dasar Negara Republik Indonesia Tahun 1945, Undangundang Nomor 39 Tahun 1999 tentang Hak Asasi Manusia (Lembaran Negara Republik Indonesia Tahun 1999 Nomor 165, Tambahan Lembaran Negara Nomor 3886) dan UndangUndang Nomor 23 Tahun 2002 tentang Perlindungan anak (Lembaran Negara Republik Indonesia Tahun 2002 Nomor 109). Sumber bahan hukum sekunder berupa bukubuku, hasil penelitian, jurnal ilmiah tentang anak jalanan, sementara bahan hukum tersier (tertiary legal resource) yakni bahan hukum yang dapat memberikan petunjuk maupun penjelasan terhadap bahan hukum primer dan sekunder seperti kamus hukum, ensiklopedia dan lain-lain.

Pengumpulan bahan hukum menggunakan dilakukan dengan cara melakukan penelusuran, pengumpulan dan studi dokumentasi terhadap bahan hukum primer, sekunder dan tersier yang dilakukan secara konvensional maupun melalui teknologi informasi (Internet, CD-Rom). Setelah bahan hukum terkumpul selanjutnya diolah melalui tahapan menstrukturkan, mendeskripsikan dan mensistematisasi bahan hukum dan selanjutnya dianalisis sebagaimana lazimnya penelitian hukum, yaitu melalui proses penalaran hukum (legal reasoning) yang logis, sistemik dan runtut dengan mengabstraksikan peraturan perundang-undangan yang berhubungan dengan perlindungan hukum anak jalanan untuk menemukan penjabaran asas-asas hukum dalam norma hukum yang bersangkutan dan norma dalam peraturan perundang-undangan. Alat analisis yang dipergunakan adalah interpretasi hukum yakni interpretasi prinsipial, sistematis dan gramatikal. Sedangkan metode analisis bahan hukum yang dipergunakan dalam penelitian ini adalah metode normatif dalam optik preskreptif $^{13}$ dengan penalaran deduktif-

\footnotetext{
${ }^{13}$ Metode ini dimaksudkan untuk secara hermeneutis menemukan kaidah hukum yang menentukan apa yang menjadi kewajiban dan hak yuridis subyek hukum dalam situasi kemasyarakatan tertentu berdasarkan dan dalam rangka tatanan hukum yang berlaku dengan selalu mengacu positivitas, ko-
} 
induktif untuk menghasilkan proposisi atau konsep sebagai jawaban dari permasalahan atau hasil/temuan penelitian

\section{PEMBAHASAN}

\section{Konsep Perlindungan Hukum Anak}

Kesadaran manusia terhadap hak asasi berasal dari keinsafan manusia terhadap pentingnya harga diri, harkat dan martabat manusia dilindungi dan dihormati karena hak kemanusiaan itu sudah ada sejak manusia dikodratkan lahir dimuka bumi, sehingga hak asasi manusia sesungguhnya bukanlah hal yang baru. Sejak Nabi Musa dibangkitkan untuk memerdekakan umat Yahudi dari perbudakan di Mesir, manusia telah menyadari tentang pentingnya penegakan hak-hak dalam membela kemerdekaan, kebenaran, dan keadilan ${ }^{14}$. Perlindungan terhadap HAM merupakan salah satu unsur pokok negara hukum baik berdasarkan konsep Rechtsstaat, The Rule of Law, maupun Negara Hukum Pancasila. Unsur-unsur lainnya seperti asas legalitas, pembagian kekuasaan negara, peradilan yang bebas dan tidak memihak, demokrasi merupakan konsekuensi lebih lanjut dari tujuan negara hukum untuk melindungi dan menjamin hak asasi warga negaranya dari tindakan kesewenangan. Karena itu, dalam penelitian ini, teori HAM relevan dijadikan landasan teori karena anak merupakan bagian dari HAM yang dijamin oleh Konstitusi. Teori HAM akan dijadikan dasar dalam membangun konsepsi perlindungan yang memposisikan anak jalanan sebagai manusia yang memiliki harkat dan martabat serta mampu berpartisipasi dalam berprestasi.

Kedudukan anak sebagai generasi muda yang akan meneruskan cita-cita luhur bangsa, calon-calon pemimpin bangsa di masa

herensi, keadilan dan martabat manusia, yang dalam implementasinya (dapat dan sering harus) memanfaatkan metode dan produk penelitian silmu sosial. Lebih lanjut lihat B. Arief Sidharta, Refleksi Tentang ....Op., cit, hlm. 218.

${ }^{14}$ Lalu Husni. (2009). Hukum Hak Asasi Manusia. Gramedia Jakarta. hlm.51. mendatang dan sebagai sumber harapan bagi generasi terdahulu, perlu mendapat kesempatan seluas luasnya untuk tumbuh dan berkembang dengan wajar baik secara rohani, jasmani, dan sosial. Perlindungan anak merupakan usaha dan kegiatan seluruh lapisan masyarakat dalam berbagai kedudukan dan peranan, yang menyadari betul pentingnya anak bagi nusa dan bangsa di kemudian hari. Jika mereka telah matang pertumbuhan fisik maupun mental dan sosialnya, maka tiba saatnya menggantikan generasi terdahulu.

Perlindungan anak adalah segala usaha yang dilakukan untuk menciptakan kondisi agar setiap anak dapat melaksanakan hak dan kewajibannya demi perkembangan dan pertumbuhan anak secara wajar baik fisik, mental, dan sosial. Perlindungan anak merupakan perwujudan adanya keadilan dalam suatu masyarakat, dengan demikian perlindungan anak diusahakan dalam berbagai bidang kehidupan bernegara dan bermasyarakat. Kegiatan perlindungan anak membawa akibat hukum, baik dalam kaitannya dengan hukum tertulis maupun hukum tidak tertulis. Hukum merupakan jaminan bagi kegiatan perrlindungan anak. Arif Gosita mengemukakan bahwa kepastian hukum perlu diusahakan demi kelangsungan kegiatan perlindungan anak dan mencegah penyelewengan yang membawa akibat negatif yang tidak diinginkan dalam pelaksanaan perlindungan anak ${ }^{15}$.

Perlindungan anak tidak boleh dilakukan secara berlebihan dan memperhatikan dampaknya terhadap lingkungan maupun diri anak itu sendiri, sehingga usaha perlindungan yang dilakukan tidak berakibat negatif. Perlindungan anak dilaksanakan rasional, bertanggungjawab dan bermanfaat yang mencerminkan suatu usaha yang efektif dan efisien. Usaha perlindungan anak tidak boleh mengakibatkan matinya inisiatif, kerativitas, dan hal-hal lain yang menye $\neg$ babkan ketergantungan kepada orang lain dan berperilaku tak terkendali, sehingga anak

${ }^{15}$ Arif Gosita. (1998). Masalah perlindungan anak. Akademindo Pressindo Jakarta. 
tidak memiliki kemampuan dan kemauan menggunakan hak-haknya dan melaksanakan kewajiban-kewajibannya.

Perlindungan anak dapat dibedakan dalam 2 (dua) bagian yaitu: (1) Perlin $\neg$ dungan anak yang bersifat yuridis, yang meliputi: perlindungan dalam bidang hukum publik dan dalam bidang hukum keperdataan. (2) Perlindungan anak yang bersifat non yuridis, meliputi: perlindungan dalam bidang sosial, bidang kesehatan, bidang pendidikan. Berdasarkan hasil seminar perlindungan anak/remaja oleh Prayuana Pusat tanggal 30 Mei 1977, terdapat dua perumusan tentang perlindungan anak yaitu ${ }^{16}$ 1) Segala daya upaya yang dilakukan secara sadar oleh setiap orang maupun lembaga pemerintah dan swasta yang bertujuan mengusa- hakan pengamanan, penguasaan, pemenuhan kesejahteraan fisik, mental, dan sosial anak dan remaja yang sesuai dengan kepentingan dan hak asasinya. 2) Segala daya upaya bersama yang dilakukan secara sadar oleh perorangan, keluarga, masyarakat, badan-badan pemerintah dan swasta untuk pengamanan, pengadaan, dan pemenuhan kesejahteraan rohaniah dan jasmaniah anak berusia 0-21 tahun, tidak dan belum pernah nikah, sesuai dengan hak asasi dan kepentingannya agar dapat mengembangkan dirinya seoptimal mungkin.

Pasal 1 ayat (2) Undang-Undang Nomor 23Tahun 2002 menentukan bahwa perlindungan anak adalah segala kegiatan untuk menjamin dan melindungi anak dan hak $\neg$ haknya agar dapat hidup, tumbuh, berkembang, dan berpartisipasi, secara optimal sesuai dengan harkat dan martabat kemanusiaan, serta mendapat perlindungan dari kekerasan dan diskriminasi. Perlindungan anak dapat juga diartikan sebagai segala upaya yang ditujukan untuk mencegah, rehabilitasi, dan memberdayakan anak yang mengalami tindak perlakuan salah (child abused), eksploitasi, dan penelantaran, agar dapat menjamin kelangsungan hidup dan tumbuh

\footnotetext{
${ }^{16}$ Irma Setyowati Sumitro. (1990). Aspek Perlindungan Hukum. Bumi Aksara. Jakarta. hlm. 14
}

kembang anak secara wajar baik fisik, mental dan sosialnya . Arif Gosita berpendapat bahwa perlindungan anak adalah suatu usaha melindungi anak dapat melaksanakan hak dan kewajibannya ${ }^{17}$.

Perlindungan hak-hak anak pada hakikatnya menyangkut langsung pengaturan dalam peraturan perundang-undangan. Kebijaksanaan, usaha dan kegiatan yang menjamin terwujudnya perlindungan hakhak anak, pertama--tama didasarkan atas pertimbangan bahwa anak-anak merupakan golongan yang rawan dan dependent di samping karena adanya golongan anakanak yang mengalami hambatan dalam pertumbuhan dan perkembangannya baik rohani, jasmani maupun sosial.

Perlindungan anak bermanfaat bagi anak dan orang tuanya serta pemerin $\neg$ tahnya, maka koordinasi kerjasama perlindungan anak perlu diadakan dalam rangka mencegah ketidakseimbangan kegiatan perlindungan anaksecarakeseluruhan ${ }^{18}$. Sehubungandengan hal ini, Abdul Hakim Garuda Nusantara, mengatakan: "Masalah perlindungan hukum bagi anak-anak merupakan satu sisi pendekatan untuk melindungi anakanak Indonesia. Masalahnya tidak sematamata bisa didekati secara yuridis, tapi perlu pendekatan lebih luas, yaitu ekonomi, sosial, dan budaya ${ }^{19}$.

Perlidungan Anak berhubungan dengan beberapa hal yang perlu mendapat perhatian yaitu ${ }^{20}$

1. Luas lingkup perlindungan:

a. Perlindunganyangpokokmeliputiantara lain: sandang, pangan, pemukiman, pendidikan, kesehatan, hukum.

b. Meliputi hal-hal yang jasmaniah dan rohaniah.

\footnotetext{
${ }^{17}$ Arief Gosita. Op, cit, hlm. 52.

${ }^{18}$ Maidin Gulton. 1997. “Aspek Hukum Pencatatan Kelahiran dalam Usaha Perlindungan Anak pada Kantor Catatan Sipil Kota Medan" Thesis, Medan Program Pasca Jarjana USU. hlm.53.

${ }^{19}$ Abdul Hakim Garuda Nusantara. (1986). Prospek Perlindungan Anak. Makalah Jakarta Seminar Perlindungan Hak-Hak Anak. hlm. 22.

${ }^{20}$ Arif Gosita . Op, cit, hlm. 4-6.
} 
c. Mengenai pula penggolongan keperluan yang primerdan sekunderyangberakibat pada prioritas pemenuhannya.

2. Jaminan pelaksanaan perlindungan:

a. Sewajarnya untuk mencapai hasil yang maksimal perlu ada jaminan terhadap pelaksanaan kegiatan perlindungan ini, yang dapat diketahui, dirasakan oleh pihak-pihak yang terlibatdalamkegiatan perlindungan.

b. Sebaiknyajaminan ini dituangkan dalam suatuperaturantertulisbaikdalambentuk undang-undang atau peraturan daerah, yang perumusannya sederhana tetapi dapat dipertanggungjawabkan serta disebarluaskan secara merata dalam masyarakat.

c. Pengaturan harus disesuaikan dengan kondisi dan situasi di Indonesia tanpa mengabaikan cara-cara perlindungan yang dilakukan di negara lain, yang patut dipertimbangkan dan ditiru (peniruan yang kritis).

Pengertian perlindungan anak dapat juga dirumuskan sebagai: (a)suatu perwujudan adanya keadilan dalam suatu masyarakat. Keadilan ini merupakan keadilan sosial, yang merupakan dasar utama perlindungan anak; (b)suatu usaha bersama melindungi anak untuk melaksanakan hak dan kewajibannya secara manusiawi dan positif; (c)suatu permasalahan manusia yang merupa-kan suatu kenyataan sosial. Menurut proporsi yang sebenarnya, secara dimen-sional perlindungan anak beraspek mental, fisik, dan sosial, hal ini berarti bahwa pemahaman, pendekatan, dan penanganan anak dilakukan secara integratif, interdisipliner, intersektoral, dan interdepartemental; (d)suatu hasil interaksi antara pihak-pihak tertentu, akibat adanya suatu interrelasi antara fenomena yang ada dan sating mempengaruhinya. Jadi perlu diteliti, dipahami, dan dihayati siapa saja (obyek dan subyek hukum) yang terlibat sebagai komponen pada adanya (eksistensi) Perlindungan Anak tersebut. Selain itu perlu juga diteliti, dipahami dan dihayati gejala mana saja mempengaruhi adanya perlindungan anak. Perlindungan anak merupakan permasalahan yang rumit dan sulit sehingga penanggulangannya harus dilakukan secara simultan dan bersama-sama; (e)suatu tindakan individu yang dipengaruhi oleh unsur-unsur sosial tertentu atau masyarakat tertentu, seperti kepentingan yang dapat menjadi motivasi, lembaga-lembaga sosial (keluarga, sekolah, pesantren, pemerintah dan sebagainya), nilainilai sosial, norma (hukum), status, peran dan sebagainya. Agar dapat memahami dan menghayati secara tepat sebab- $\neg$ sebab orang melakukan Perlindungan Anak sebagai suatu tindakan individu (sendiri-sendiri atau bersama-sama), maka dipahami unsurunsur struktur sosial yang terkait; (f)dapat merupakan suatu tindakan hukum (yuridis) yang dapat mempunyai akibat hukum yang harus diselesaikan dengan berpedoman dan berdasarkan hukum. Perlu adanya pengaturan berdasarkan hukum untuk mencegah dan menindak pelaksanaan Perlindungan Anak yang menimbulkan penderitaan mental, fisik, dan sosial pada anak yang bersangkutan; ( $\mathrm{g}$ ) harus diusahakan dalam berbagai bidang penghidupan dan kehidupan keluarga, bermasyarakat,bernegara,dan berbangsa. Taraf Perlindungan Anak pada suatu masyarakat atau bangsa merupakan tolok ukur taraf peradaban masyarakat dan bangsa tersebut; (h) merupakan suatu bidang pembangunan hukum nasional. Mengabaikan masalah Perlindungan Anak akan mengganggu pembangunan nasional serta kesejahteraan rakyat maupun anak. Ikut serta dalam pembangunan nasional adalah hak dan kewajiban setiap warga negara;(i) merupakan bidang pelayanan sukarela (voluntarisme) yang luas lingkupnya dengan gaya baru (inovatif, inkonvensional) ${ }^{21}$.

Dasar pelaksanaan perlindungan anak adalah 1) Dasar Filosofls yaitu Pancasila dasar kegiatan dalam berbagai bidang kehidupan keluarga, bermasyarakat, bernegara, dan

${ }^{21}$ Arif Gosita. (1999). "Aspek Hukum Perlindungan Anak Dan Konvensi Hak-Hak Anak". Era Hukum. Jurnal Ilmiah Ilmu Hukum, No.4/Th.V/April 1999. Fakultas Hukum Tarumanagara. Jakarta. hlm. 264-265. 
berbangsa, serta dasar filosofis pelaksanaan perlindungan anak. 2) Dasar Teoritis yaitu pelaksanaan perlindungan anak harus sesuai dengan etika profesi yang berkaitan, untuk mencegah perilaku menyimpang dalam pelaksanaan kewenangan, kekuasaan, dan kekuatan dalam pelaksanaan perlindungan anak. 3) Dasar Yuridis yaitu pelaksanaan perlindungan anak harus didasarkan pada Undang-Undang Dasar 1945 Negara Republik Indonesia dan berbagai peraturan perundangundangan lainnya yang berlaku. Penerapan dasar yuridis ini harus secara integratif, yaitu penerapan terpadu menyangkut peraturan perundang-undangan dari berbagai bidang hukum yang berkaitan ${ }^{22}$.

Pelaksanaan perlindungan anak, harus memenuhi syarat antara lain: merupakan pengembangan kebenaran, keadilan, dan kesejahteraan anak; harus mempunyai landasan filsafat, etika, dan hukum secara rasional positif, dapat dipertanggungjawabkan bermanfaat untuk yang bersangkutan mengutamakan perspektif kepentingan yang diatur bukan perspektif kepentingan yang mengatur, tidak bersifat aksidental dan komplimenter, tetapi harus dilakukan secara konsisten, mempunyai rencana operasional, memperhatikan unsur-unsur manajemen melaksanakan respons keadilan yang restoratif (bersifat pemulihan), tidak merupakan wadah dan kesempatan orang mencari keuntungan pribadi/kelompok, anak diberi kesempatan untuk berpartisipasi sesuai situasi dan kondisinya, berdasarkan citra yang tepat mengenai anak manusia ${ }^{23}$.

Perlindungan anak dapat dilakukan secara langsung maupun secara tidak langsung. Secara langsung maksudnya kegiatannya langsung ditujukan kepada anak yang menjadi sasaran penanganan langsung. Kegiatan seperti ini dapat berupa antara lain dengan cara melindungi anak dari berbagai ancaman dari luar dan dalam dirinya, mendidik, membina, mendampingi anak dengan berbagai cara, mencegah anak kelaparan dan mengusahakan kesehatannya dengan berbagai cara, menyediakan sarana pengembangan diri dan sebagai-nya. Perlindungan anak secara tidak langsung yaitu kegiatan tidak langsung ditujukan kepada anak, tetapi orang lain yang melakukan/terlibat dalam usaha perlindungan anak. Usaha perlindungan demikian misalnya dilakukan oleh orangtua atau yang terlibat dalam usaha-usaha perlindungan anak terhadap berbagai ancaman dari luar ataupun dari dalam diri anak, mereka yang bertugas mengasuh, membina, mendampingi anak dengan berbagai cara mereka yang terlibat mencegah anak kelaparan, mengusahakan kesehatan, dan sebagainya dengan berbagai cara, mereka yang menyediakan sarana mengembangkan diri anak dan sebagainya. Setiap orang mempunyai kepentingan sendiri, yang tidak sama, tetapi juga kadang-kadang bertentangan, untuk itu diperlukan aturan hukum dalam menata kepentingan tersebut, yang menyangkut kepen $\neg$ tingan anak diatur oleh ketentuan-ketentuan hukum yang berkaitan dengan perlindungan anak, yang disebut dengan Hukum Perlindungan Anak.

\section{Tanggungjawab Perlindungan Anak}

Konsekuensi telah diratifikasi terhadap instrumen-instrumen hak asasi manusia internaional (Konvensi Hak Anak), negara akan memiliki kewajiban dan tanggung jawab untuk mendukung dan melaksanakan setiap upaya pemajuan hak asasi manusia sipil, politik, ekonomi, sosial dan budaya baik di tingkat nasional maupun intternasional tidak terkecuali dalam proses pembangunan .

Kewajiban dan tangggung jawab negara dalam kerangka pendekatan berbasis hak asasi manusia bisa dilihat dalam tiga bentuk:

1. Menghormati (obligation to respect) merupakan kewajiban negara untuk tidak turut campur untuk mengatur warga negaranya ketika melaksanakan haknya. Dalam hal ini negara memiliki kewajiban untuk tidak melakukan tindakan-tindakan

\footnotetext{
${ }^{22}$ Ibid., hlm. 266-267

${ }^{23} \mathrm{Ibid} ., \mathrm{hlm}$. 265-266.
} 
yang akan menghambat pemenuhan dari seluruh hak asasi anak ${ }^{24}$.

2. Melindungi (obligation to protect) merupakan kewajiban negara agar bertindak aktif untuk memberikan jaminan perlindungan terhadap hak asasi warganya. Dalam hal ini negara berkewajiban untuk mengambil tindakan-tindakan untuk mencegah pelanggaran semua hak asasi anak oleh pihak ketiga ${ }^{25}$.

3. Memenuhi(obligation to fulfill) merupakan kewajiban dan tanggung jawab negara unuk bertindak secara aktif agar semua warga negaranya itu bisa terpenuhi hak-haknya. Negara berkewajiban untuk mengambil langkah-langkah legislatif, administratif, hukum, dan tindakan-tindakan lain untuk merealisasikan secara penuh hak asasi anak 26 .

Kewajiban untuk menghormati, melindungi dan memenuhi hak anak, masingmasing mengandung unsur kewajiban negara dan masyarakat untuk bertindak (obligation to conduct) serta kewajiban untuk berdampak (obligation to result):

a. Kewajiban untuk bertindak (obligation to conduct) mensyaratkan negara melakukan langkah-langkah tertentu untuk melaksanakan pemenuhan suatu hak, yaitu melindungi hak anak sesuai dengan peraturan yang mengaturnya (UndangUndang Nomor 23 Tahun 2002 tentang Perlindungan Anak) ${ }^{27}$.

b. Kewajiban untuk berdampak (obligation to result) yaitu mendorong negara untuk mencapai sasaran tertentu guna memenuhi standar substantif yang tertentu. Negara memberikanperhatianyangkhususdanterus menerus tentang perlindungan anak jalanan di semua kehidupan sehingga pemenuhan, penghormatan dan perlindungan bagi anak dapat tercapai sesuai dengan standar HAM Internasional (Konvensi Hak Anak) ${ }^{28}$.

\footnotetext{
${ }^{24}$ Pembangunan Berbasis Hak Asasi Manusia. (2007). sebuah panduan kerja antara Komisi Nasional Hak Asasi Manusia dengan Australia Government.

${ }^{25} \mathrm{Ibid}$., hlm. 8.

${ }^{26}$ Ibid., hlm. 8.

${ }^{27}$ Ibid., hlm. 8.

${ }^{28}$ Ibid., hlm. 9.
}

Perlindungan anak dilakukan oleh setiap orang baik orangtua, keluarga, masyarakat, pemerintah maupun negara. Pasal 20 Undang-Undang Nomor 23 Tahun 2002 menentukan:'Negara, pemerintah, masyarakat, keluarga, dan orangtua berkewajiban dan bertanggungjawab terhadap penyelenggaraan perlindungan anak." Jadi yang mengusahakan perlindungan anak adalah setiap anggota masyarakat sesuai dengan kemampuannya dengan berbagai macam usaha dalam situasi dan kondisi tertentu. Setiap warga negara ikut bertanggung jawab terhadap dilaksanakannya perlindungan anak demi kesejahteraan anak. Kebahagiaan anak merupakan kebahagiaan bersama, kebahagiaan yang dilindungi adalah kebahagiaan yang melindungi. Tidak ada keresahan pada anak karena perlindungan anak dilaksanakan dengan baik, anak menjadi sejahtera. Kesejahteraan anak mempunyai pengaruh positif terhadap orangtua, keluarga, masyarakat, pemerintah, dan negara. Perlindungan anak bermanfaat bagi anak dan orangtua, keluarga, masyarakat, pemerintah, dan negara. Koordinasi kerjasama kegiatan perlindungan anak perlu dilakukan dalam rangkamencegahketidakseimbangankegiatan perlindungan anak secara keseluruhan.

Kewajiban dan tanggungjawab Negara dan Pemerintah dalam usaha perlindungan anak diatur dalam Undang-Undang Nomor 23 Tahun 2002 yaitu:

a. Menghormatidanmenjaminhakasasisetiap anak tanpa membedakan suku, agama, ras, golongan, jenis kelamin, etnik, budaya, dan bahasa, sta $\neg$ tus hukum anak, urutan kelahiran anak dan kondisi fisik dan/atau mental (Pasal 21);

b. Memberikandukungansaranadanprasarana dalam penyelenggaraan perlindungan anak (Pasal 22);

c. Menjaminperlindungan, pemeliharaan, dan kesejahteraan anak dengan memperhatikan hak dan kewajiban orangtua, wali atau orang lain yang secara umum bertanggungjawab terhadap anak dan mengawasi 
penyel $\neg$ enggaraan perlindungan anak (Pasal 23);

d. Menjamin anak untuk mempergunakan haknya dalam menyampaikan nendapat sesuai dengan usia dan tingkat kecerdasan anak (Pasal 24).

Kewajiban dan tanggungjawab masyarakat terhadap perlindungan anak dilaksanakan melalui kegiatan peran masyarakat dalam penyelenggaraan perlindungan anak (Pasal 25 Undang-Undang Nomor 23 Tahun 2002). Kewajiban dan tanggung $\neg$ jawab keluarga dan orangtua dalamusaha perlindungananakdiatur dalam Pasal 26 Undang-Undang Nomor 23 tahun 2002 yaitu : (a)mengasuh,memelihara, mendidik, melindungi anak; (b)menumbuh kembangkan anak sesuai dengan kemampuan, bakat dan minatnya dan; (c)mencegah terjadinya perkawinan pada usia anak-anak. Dalam hal orangtua tidak ada, atau tidak diketahui keberadaannya atau karena suatu sebab, tidak dapat dilaksanakan kewajiban dan tangungjawabnya, maka kewajiban dan tanggungjawab sebagaimana yang diimaksud dalam ayat (1) dapat beralih kepada keluarga, yang dilaksanakan sesuai dengan ketentuan peraturan perundang-undangan yang berlaku.

\section{Konsep Ham dalam UUD NRI 1945 Pasca Reformasi}

Memasukkan nilai-nilai dan ketentuan tentang hak-hak asasi manusia ke dalam pasal-pasal konstitusi merupakan salah satu ciri konstitusi modern. Setidaknya, dari 120an konstitusi di dunia, ada lebih dari 80 persen diantaranya yang telah memasukkan pasalpasal hak asasi manusia, utamanya pasalpasal dalam DUHAM ${ }^{29}$. Perkembangan ini sesungguhnya merupakan konsekuensi tata pergaulan bangsa-bangsa sebagai bagian dari komunitas internasional, utamanya melalui organ Perserikatan Bangsa-Bangsa.

Demikian juga adanya peralihan rezim dari orde baru ke reformasi, sedikit

${ }^{29}$ R.Herlambang Perdana Wiratman. (2007). Hak-Hak Konstitusional Warga Negara Setelah Amandemen UUD NKRI 1945 ; Konsep, Pengaturan dan Dinamika Implementasi. Jurnal Hukum Panta Rei. 1 (1), hlm. 3. banyaknya membawa perubahan mendasar terhadap konstitusi republik Indonesia. Bahkan perubahan UUD Negara Republik Indonesia Tahun 1945 telah dianggap sebagai puncak aspirasi gerakan reformasi itu sendiri. Konsepsi HAM yang sebelumnya tidak tercantum secara tegas dalam UUD Negara Republik Indonesia Tahun 1945, setelah perubahan kedua pada tahun 2000, ketentuan mengenai hak asasi manusia dan hak warga negara dalam UUD Negara Republik Indonesia Tahun 1945 telah mengalami perubahan yang sangat mendasar. Meskipun dalam prosesnya diwarnai perdebatan seputar isu mengenai hak bebas dari pemberlakuan undang-undang yang berlaku surut (nonretroactivity principle) yakni Pasal 28 I UUD Negara Republik Indonesia Tahun 1945.

Masuknya ketentuan ini dipandang oleh kalangan aktifis hak asasi manusia dan aktifis pro-reformasi yang tergabung dalam Koalisi untuk Konstitusi Baru sebagai "sabotase" terhadap upaya mengungkapkan pelanggaran berat hak asasi manusia di masa lalu, khsususnya di masa Orde Baru. Alasannya adalah bahwa pasal tersebut dapat digunakan oleh para pelaku pelanggaran HAM di masa lalu untuk menghindari tuntutan hukum. Undang-Undang Pengadilan Hak Asasi Manusia dan Undang-Undang Komisi Kebenaran dan Rekonsiliasi, yang lahir setelah Amandemen Kedua menjadi senjata yang tak dapat digunakan untuk kasus-kasus pelanggaran HAM di masa lalu. Sementara anggota Majelis Permusyawaratan Rakyat beralasan bahwa adanya pasal itu sudah lazim dalam instrumen internasional hak asasi manusia, khususnya dalam Kovenan Internasional tentang Hak Sipil dan Politik (KIHSP).

Terlepas dari kontroversi yang dipaparkan di atas, amandemen kedua tentang Hak Asasi Manusia merupakan sebuah prestasi yang dicapai Majelis Permusyawaratan Rakyat pasca Orde Baru. Amandemen Kedua itu telah mengakhiri perjalanan panjang bangsa ini dalam memperjuangkan jaminan perlindungan konstitusional hak 
asasi manusia di dalam Undang-Undang Dasar. Mulai dari awal penyusunan UndangUndang Dasar pada tahun 1945, Konstituante (1957-1959), awal Orde Baru (1968) dan berakhir pada masa reformasi saat ini merupakan perjalanan panjang diskursus hak asasi manusia dalam sejarah politikhukum Indonesia sekaligus menjadi bukti bahwa betapa menyesatkan pandangan yang menyatakan hak asasi manusia tidak dikenal dalam budaya Indonesia.

Menurut Jilmy, materi yang semula hanya berisi tujuh butir ketentuan jaminan terhadap hak asasi manusia pada UUD Negara Republik Indonesia Tahun 1945 sebelum amandemen, sebanarnya tidak sepenuhnya dapat disebut sebagai jaminan terhadap HAM. Melalui amandemen kedua, perumusan jaminan hak asasi manusia jauh lebih baik, lebih lengkap dan menjadikan UUD Negara Republik Indonesia Tahun 1945 sebagai salah satu undang-undang dasar yang paling lengkap memuat perlindungan terhadap hak asasi manusia ${ }^{30}$. Dengan disahkannya perubahan kedua UUD Negara Republik Indonesia Tahun 1945 pada tahun 2000, dan apabila meterinya digabung dengan berbagai ketentuan yang terdapat dalam undangundang yang berkenaam dengan hak asasi manusia, Jimly membagi dari keseluruhan norma hukum mengenai hak asasi manusia kedalam empat kelompok yang memuat 37 butir ketentuan ${ }^{31}$.

Kelompok pertama adalah kelompok ketentuan yang menyangkut hak-hak sipil yang meliputi:

a. Setiaporangberhakhidup,mempertahankan hidup dan kehidupannya; ${ }^{32}$

b. Setiap orang berhak untuk bebas dari penyiksaan, perlakuan atau hukuman

\footnotetext{
${ }^{30}$ Jimly Asshiddiqie. (2006). Pokok-Pokok Hukum Tata Negara Pasca Reformasi, hlm. 639.

${ }^{31}$ Jimly Asshiddiqie. (2006). Pengantar Ilmu Hukum Tata Negara. Jakarta: Sekjend dan Kepaniteraan Mahkamah Konstitusi RI, Jakarta : PT. Bhuana Ilmu Populer. hlm. 93.

${ }^{32}$ Lihat Pasal 28 A UUD Negara Republik Indonesia Tahun 1945 dan Pasal 9 Ayat (1) UU No. 39 Tahun 1999 tentang Hak Asasi Manusia
}

lain yang kejam, tidak manusiawi dan merendahkan martabat kemanusiaan; ${ }^{33}$

c. Setiap orang berhak untuk bebas dari segala bentuk perbudakan; ${ }^{34}$

d. Setiap orang bebas memeluk agama dan beribadat menurut agamanya; ${ }^{35}$

e. Setiap orang berhak untuk bebas memiliki keyakinan, pikiran dan hati nurani;

f. Setiap orang berhak untuk diakui sebagai pribadi dihadapan hukum; ${ }^{36}$

g. Setiap orang berhak atas perlakuan yang samadihadapanhukumdan pemerintahan; ${ }^{37}$

h. Setiap orang berhak untuk tidak dituntutatas dasar hukum yang berlaku surut $; 38$

i. Setiap orang berhak untuk membentuk keluarga dan melanjutkan keuturunan melalui perkawinan yang sah; ${ }^{39}$

j. Setiap orang berhak atas status kewarganegaraan; ${ }^{40}$

k. Setiaporangberhakuntukbertempattinggal di wilayah negaranya, meninggalkan, dan kembali ke negaranya; ${ }^{41}$

1. Setiap orang berhak memperoleh suaka politik $^{42}$

m. Setiap orang berhak bebas dari segala bentuk perlakuan diskriminatif dan berhak mendapatkan perlindungan hukum dari

${ }^{33}$ Hak untuk tidak disiksa termasuk golongan hak asasi manusia yang tidak dapat dikurangi dalam keadaan apapun. Lihat Pasal 28 I Ayat (1) UUD Negara Republik Indonesia Tahun 1945 dan Pasal 33 Ayat

(1) UU No. 39 Tahun 1999 tentang Hak Asasi Manusia ${ }^{34}$ Lihat Pasal 28 I Ayat (1) UUD Negara Republik Indonesia Tahun 1945 dan Pasal 20 Ayat (1 \& 2) UU No. 39 Tahun 1999 tentang Hak Asasi Manusia

${ }^{35}$ Lihat Pasal 28 I Ayat (1) UUD Negara Republik Indonesia Tahun 1945 dan Pasal 20 Ayat (1 \& 2) UU

No. 39 Tahun 1999 tentang Hak Asasi Manusia

${ }^{36}$ Lihat Pasal 28 D Ayat (1) UUD Negara Republik Indonesia Tahun 1945 dan Pasal 29 Ayat (2) UU No. 39 Tahun 1999 tentang Hak Asasi Manusia

${ }^{37}$ Pasal 28 D ayat (3) UUD Negara Republik Indonesia Tahun 1945

${ }^{38}$ Pasl 28 I UUD 1945 Ayat (1)

${ }^{39}$ Pasal 28 B Ayat (1) UUD Negara Republik Indonesia Tahun 1945 dan Pasal 10 UU No. 39 Tahun 1999 tentang Hak Asasi Manusia

${ }^{40}$ Pasal 28 D Ayat (4) UUD Negara Republik Indonesia Tahun 1945 dan Pasal 26 UU No. 39 Tahun 1999 tentang Hak Asasi Manusia

${ }^{41}$ Pasal 28 E Ayat (1) UUD Negara Republik Indonesia Tahun 1945 dan Pasal 27 Ayat (1\&2) UU No. 39 Tahun 1999 tentang Hak Asasi Manusia

${ }^{42}$ Pasal 28 G Ayat (2) UUD Negara Republik Indonesia Tahun 1945 
perlakuan yang bersifat diskriminatif tersebut. ${ }^{43}$

Kedua, kelompok hak-hak politik, ekonomi, sosial dan budaya yang meliputi :

a. Setiap warga negara berhak untuk berserikat (freedom of association), berkumpul (freedom of peacefulassembly), dan menyatakan pendapatnya secara damai (freedom of expression) ${ }^{44}$

b. Setiap warga berhak untuk memilih dan dipilih dalam pemilihan umum; ${ }^{45}$

c. Setiap warga negara dapat diangkat untuk menduduki jabatan-jabatan publik;

d. Setiap orang berhak untuk memperoleh dan memilih pekerjaan yang sah dan layak bagi kemanusiaan; dan mendapat imbalan dan mendapat perlakuan yang layak dalam hubungan kerja yang berkeadilan. ${ }^{46}$

e. Setiap orang berhak mempunyai hak milik pribadi; ${ }^{47}$

f. Setiap warga negara berhak atas jaminan sosial yang dibutuhkan untuk hidup layak dan memungkinkan pengembangan dirinya sebagai manusia yang bermartabat; ${ }^{48}$

g. Setiap orang berhak untuk berkomunikasi dan memperoleh informasi; ${ }^{49}$

h. Setiap orang berhak untuk memperoleh dan memilih pendidikan dan pengajaran; ${ }^{50}$

i. Setiap orang berhak mengembangkan dan memperoleh manfaat dari ilmu

${ }^{43}$ Dalam Pasal Pasal 28 I Ayat (2) UUD Negara Republik Indonesia Tahun 1945 tujuh hak asasi manusia yang termuat dalam pasal ini merupakan hak asasi manusia yang tidak dapat dikurangi dalam keadaan apapun.

${ }^{44}$ Hak mengenai kebebasan berpendapat menurut Pasal 28 E Ayat (3) UUD Negara Republik Indonesia Tahun 1945 tergolong hak asasi manusia yang tidak dapat dikurangi dalam keadaan apapun.

${ }^{45}$ Pasal 43 Ayat (1) UU No. 39 Tahun 1999 tentang Hak Asasi Manusia

${ }^{46}$ Pasal 28 D Ayat (2) UUD Negara Republik Indonesia Tahun 1945 dan Pasal 28 UU No. 39 Tahun 1999 tentang Hak Asasi Manusia

${ }^{47}$ Pasal 28 H Ayat (4) UUD Negara Republik Indonesia Tahun 1945 dan Pasal 36 Ayat (1) UU No. 39 Tahun 1999 tentang Hak Asasi Manusia

${ }^{48}$ Pasal 28 H Ayat (3) UUD Negara Republik Indonesia Tahun 1945 dan Pasal 42 Ayat (1) UU No. 39 Tahun 1999 tentang Hak Asasi Manusia

${ }^{49}$ Pasal 28 F UUD Negara Republik Indonesia Tahun 1945 dan Pasal 14 Ayat (1) UU No. 39 Tahun 1999 tentang Hak Asasi Manusia

${ }^{50}$ Pasal 28 E Ayat (1) UUD Negara Republik Indonesia Tahun 1945 pengetahuan dan tekhnologi, seni dan budaya untuk peningkatan kualitas hidup dan kesejahteraan umat manusia. ${ }^{51}$

j. Negara menjamin atas penghormatan identitas budaya dan hak-hak masyarakat lokal selaras dengan perkembangan zaman dan tingkat peradaban bangsa-bangsa; ${ }^{52}$

Negara mengakui setiap budaya sebagai bagian dari kebudayaan nasional;

Ketiga, kelompok hak-hak khusus dan hak atas pembangunan yang meliputi $:^{53}$

a. Setiap warga negara yang menyandang masalah sosial, termasuk kelompok masyarakat yang terasing dan yang hidup dilingkungan terpencil, berhak mendapat kemudahan dan perlakuan khusus untuk memperoleh kesempatan yang sama;

b. Hak perempuan dijamin dan dilindungi untuk mendapat kesetaraan gender dalam kehidupan nasional;

c. Hak khusus yang melekat pada diri perempuan yang dikarenakan oleh fungsi reproduksinya dijamin dan dilindungi oleh hukum; ${ }^{54}$

d. Setiap anak berhak atas kasih sayang, perhatian dan perlindungan orang tua, keluarga, masyarakat, dan negara bagi pertumbuhan fisik dan mental serta perkembangan pribadinya;

e. Setiap warga negara berhak untuk berperansertadalampengelolaandanturutmenikmati manfaatyang diperoleh darikekayaan alam;

f. Setiap orang berhak atas lingkungan hidup yang bersih dan sehat; ${ }^{55}$

g. Kebijakan, perlakuan atau tindakan khusus yang bersifat sementara dan dituangkan dalam peraturan perundang-undangan yang sah,yang dimaksudkanuntukmenyetarakan tingkat perkembangan kelompok tertentu

\footnotetext{
${ }^{51}$ Pasal 28 C Ayat (1) UUD Negara Republik Indonesia Tahun 1945 dan Pasal 13 Ayat (1) UU No. 39 Tahun 1999 tentang Hak Asasi Manusia

${ }^{52}$ Pasal 28 I Ayat (3) UUD Negara Republik Indonesia Tahun 1945

${ }_{53}^{5}$ Jimly Asshiddiqie, Pengantar Ilmu Hukum Tata Negara, Jakarta : Sekjend dan Kepaniteraan Mahkamah Konstitusi RI, 2006, h. 93-96.

${ }^{54}$ Pasal 49 ayat (3) UU No. 39 Tahun 1999 tentang Hak Asasi Manusia

${ }^{55}$ Pasal 28 H Ayat (1) UUD Negara Republik Indonesia Tahun 1945
} 
yang mengalami perlakuan diskriminatif dengan kelompok-kelompok lain dalam masyakarat dan perlakuan khusus tersebut tidak termasuk dalam pengertian diskriminatif.

Keempat, kelompok yang mengatur mengenai tanggung jawab negara dan kewajiban asasi manusia yang meliputi :

a. Setiap orang wajib menghormati hak asasi manusia orang lain dalam tertib kehidupan masyarakat, berbangsa dan bernegara; ${ }^{56}$

b. Dalam menjalankan hak dan kebebasannya setiap orang wajib tunduk pada pembatasan yang ditetapkan oleh undang-undang dengan maksud semata-mata untuk menjamin pengakuan dan penghormatan atashakdankebebasanoranglainsertauntuk memenuhi tuntutan keadilan sesuai dengan nilai-nilai agama, moralitas, kesusilaan, keamanan dam ketertiban umum dalam masyarakat yang demokratis; ${ }^{57}$

c. Negara bertanggung jawab atas perlindungan, pemajuan, penegakan dan pemenuhan hak-hak asasi manusia, ${ }^{58}$

d. Untukmenjamin pelaksanaan hak-hak asasi manusia, dibentuk Komisi Nasional Hak AsasiManusiayang bersifatindependendan tidakmemihakyangpembentukan,susunan, dan kedudukannya diatur undang-undang. Disamping Pasal 28 A sampai dengan Pasal 28 J Negara Republik Indonesia Tahun 1945 pasca amandemen, ada juga beberapa pasal yang dapat dikaitkan dengan hak asasi manusia, yakni Pasal 29 Ayat (2) :’Negara menjamin kemerdekaan tiap-tiap penduduk untuk memeluk agamanya masing-masing dan untuk beribadat menurut agamanya dan kepercayaannya itu.'Pasal tersebut dianggap Jimly sebagai Pasal yang paling memenuhi syarat untuk disebut sebagai Pasal hak asasi manusia yang diwarisi dari naskah asli UUD Negara Republik Indonesia Tahun 1945. Sedangkan ketentuan lainnya seperti Pasal 27 ayat (1) dan (2), Pasal 28, Pasal 30 Ayat (1),

\footnotetext{
${ }^{56}$ Pasal 28 J Ayat (1) UUD Negara Republik Indonesia Tahun 1945

${ }^{57}$ Pasal 28 J ayat (2) UUD 1945

${ }^{58}$ Pasal 71 UU No. 39 Tahun 1999 tentang Hak Asasi Manusia
}

Pasal 31 ayat (1), serta Pasal 32 Ayat (1) dan (2) UUD 1945 sebelum perubahan bukanlah ketentuan mengenai jaminan hak asasi manusia dalam arti sebenarnya, melainkan hanya berkaitan dengan pengertian hak warga negara. ${ }^{59}$

Pasal 27 Ayat (1) menentukan :'Segala warga negara bersamaan kedudukannya didalam hukum dan pemerintahan dan wajib menjunjung hukum dan pemerintahan itu dengan tidak ada kecualinya". Ayat (2) ditentukan :'Tiap-tiap warga negara berhak atas pekerjaan dan penghidupan yang layak bagi kemanusiaan".

Pasal 30 ayat (1) menentukan: "Tiaptiap warga negara berhak dan wajib ikut serta dalam usaha perthanan dan keamanan negara".

Pasal 31 ayat (1) menentukan: "Setiap warga negara berhak mendapat pendidikan".

Ketentuan diatas terkait dengan warga negara, bukan kepada seluruh manusia yang hidup di wilayah negara Indonesia. Dengan kata lain, keberadaan warga negara asing tidak terlindungi atau terakomodir dalam ketentuanketentuan tersebut. Ketentuan mengenai warga negara jelas berbeda dari hak asasi yang berlaku bagi semua manusia, terlepas dari apa status kewarganegaraannya. Meskipun yang bersangkutan berkwarganegaraan asing, sepanjang yang bersangkutan hidup dan tinggal berada diwilayah hukum Republik Indonesia, maka hak-hak dasarnya sebagai manusia wajib dihormati dan dilindungi, karena yang bersangkutan memiliki hak-hak yang wajib dihormati.

Pasal 28 UUD Negara Republik Indonesia Tahun 1945 sebelum perubahan juga sebenarnya lebih tidak tegas lagi dalam memberikan jaminan konstitusional hak asasi manusia, melainkan hanya menyatakan bahwa jaminan itu akan diatur atau ditetapkan dengan undang-undang. Pasal ini merupakan rumusan asli UUD Negara Republik Indonesia Tahun 1945 yang disahkan pada tanggal 18

\footnotetext{
${ }^{59}$ Jimly Asshiddiqie. (2006). Pokok-Pokok Hukum Tata Negara Pasca Reformsi. Jakarta : PT. Bhuana Ilmu Populer. hlm. 645
} 
Agustus 1945.Kemerdekaan berserikat dan berkumpul, mengeluarkan pikiran dengan lisan dan tulisan dan sebagainya ditetapkan dengan undang-undang. ${ }^{60}$

Substansi ketentuan tersebut kemudian termuat juga dalam Pasal 28 E Ayat (3) UUD Negara Republik Indonesia Tahun 1945 yang menentukan: "Setiap orang berhak atas kebebasan berserikat, berkumpul, dan mengeluarkan pendapat". ${ }^{61}$

Mengenai ketentuan pasal 28 yang merupakan redaksi asli UUD UUD Negara Republik Indonesia Tahun 1945 sebelum amandemen, Jimly berpendapat bahwa sebaiknya pasal 28 tersebut tidak perlu dicantumkan lagi dan diganti seluruhnya dengan pasal 28 A sampai dengan Pasal 28 J. ${ }^{62}$

Perkembangan pergaulan internasional baik yang bersifat bilateral maupun global sangat berdampak pada percepatan arus globalisasi masyarakat dunia. Hal ini disebabkan karena semakin meningkatnya teknologi informasi dan komunikasi yang membuat dunia kian egaliter dan tanpa batas. Dalam masyarakat internasional, perjanjian internasional memainkan peranan yang sangat penting dalam mengatur kehidupan dan pergaulan antar negara. Oleh karenanya perkembangan pengaturan hukum hak asasi manusia di dunia internasional juga membawa dampak yang begitu besar bagi Indonesia dalam rangka melakukan serangkaian legislasi kebijakan yang berkaitan dengan pengaturan, perlindungan dan penegakan hak asasi manusia.

Perjanjian internasional tersebut pada hakikatnya merupakan sumber hukum internasional yang utama, yakni instrumeninstrumen yuridis yang menampung kehendak dan persetujuan negara atau subjek hukum internasional lainnya untuk mencapai tujuan bersama $^{63}$. Dengan demikian, perjanjian

\footnotetext{
${ }^{60}$ Pasal 28 UUD Negara Republik Indonesia Tahun 1945

${ }^{61}$ Pasal 28 E Ayat (3) UUD Negara Republik Indonesia Tahun 1945.

${ }^{62}$ Jimly Asshiddiqie. (2007). Pokok-Pokok Hukum Tata Negara Pasca Reforms. Jakarta: PT. Bhuana Ilmu Populer. hlm 646.

${ }^{63}$ Boer Mauna. (2005). Hukum Internasional; Pengertian, Peranan dan Fungsi dalam Era Dinamika
}

internasional merupakan semua perjanjian yang dibuat oleh negara sebagai salah satu subyek hukum internasional yang berisi ketentuan-ketentuan yang mempunyai akibat hukum $^{64}$. Perjanjian internasional yang dibuat dengan wajar akan menimbulkan kewajiban-kewajiban yang mengikat bagi negara-negara peserta (para pihak), dan kekuatan mengikat perjanjian internasional terletak dalam adagium Pacta Sunt Servanda, yang mewajibkan negara-negara untuk melaksanakan dengan itikad baik kewajibankewajibannya.$^{65}$

Namun demikian perbincangan mengenai eksistensi hukum internasional seringkali diletakkan dalam konteks dua ajaran dualis (dualistic school) dan ajaran monis (monistic school). Ajaran yang pertama melihat hukum internasional dan nasional sebagai dua sistem hukum yang terpisah dan berdiri sendiri-sendiri. Sedangkan ajaran yang kedua melihat hukum internasional dan nasional sebagai bagian integral dari sistem yang sama. Meskipun kedua ajaran tersebut dalam praktiknya masih tumpang tindih, biasanya negara yang dirujuk menganut ajaran monis adalah Inggris dan Amerika Serikat. Tetapi jika kita lihat, hanya Amerika Serikat yang secara tegas menyatakan dalam konstitusinya bahwa "all treaties made or which shall be made, under the Authority of the United States, shall be the supreme Law of the Land; and the judges in every State shall be bound thereby" ${ }^{66} \mathrm{Hal}$ inilah yang membedakan dengan Indonesia, Indonesia sepertinya lebih dekat dengan ajaran yang pertama, sebagaimana terlihat dalam ketentuan Pasal 11 Ayat ( $r$ ) UUD Negara Republik Indonesia Tahun 19ะ0," yakni mensyaratkan dalam

\footnotetext{
Global. Bandung : Penerbit Alumni. hlm. 82

${ }^{64}$ Mochtar Kusumaatmadja. (1982). Pengantar Hukum Internasional. Bandung: Bina Cipta. hlm..84.

${ }^{65} \mathrm{~F}$. Isjwara. 1972. Pengantar Hukum Internasional. Bandung : Alumni. hlm. 201

${ }^{6}$ Dikutip dari Oscar Schachter, "The Charter and the Constitution: The Human RightsProvisions in American Law", Vand. L. Rev, 643 Vil 4, hlm. 643, 1951.

${ }^{67}$ Ketentuan itu berbunyi, "Presiden dalam membuat perjanjian internasional lainnya yang menimbulkan akibat yang luas dan mendasar bagi kehidupan rakyat yang terkait dengan beban keuangan negara,
} 
proses pemberlakuan hukum internasional ke dalam hukum nasional terlebih dahulu mengambil langkah transformasi melalui proses perundang-undangan domestik. Proses ini yang kemudian kita kenal dengan istilah ratifikasi atau aksesi.

Proses pengesahan perjanjian internasional juga telah diatur secara tersendiri dalam Undang-Undang Nomor 24 Tahun 2000 tentang Perjanjian Internasional. Undangunadang ini mengatur mekanisme pengesahan konvensi internasional yang dapat dilakukan dengan beberapa cara, diantaranya dalam bentuk ratifikasi (ratification), aksesi (accession), penerimaan (acceptance) dan penyetujuan (approval) ${ }^{68}$. Berdasarkan Pasal 9 ayat (2) Undang-Undang Nomor 24 Tahun 2000 tentang Perjanjian Internasional, disebutkan bahwa dalam praktiknya ada dua macam pengesahan perjanjian internasional di Indonesia, yaitu dengan Undang-Undang dan Keputusan Presiden. Dalam menentukan ratifikasi perjanjian internasional (akan diratifikasi dengan Undang- undang atau dengan keppres), dilihat dari substansi atau materi perjanjian bukan berdasarkan bentuk dan nama (nonmenclature) perjanjian. Klasifikasi menurut materi perjanjian dimaksud agar terciptanya kepastian hukum dan keseragaman atas bentuk pengesahan perjanjian internasional dengan undangundang ${ }^{69}$.

$\overline{\text { dan/atau mengharuskan perubahan atau pembentukan }}$ undang-undang harus dengan persetujuan Dewan Perwakilan Rakyat".

${ }^{68}$ Ratifikasi yaitu apabila Negara yang akan mengesahkan suatu perjanjian internasional turut menandatangani naskah perjanjian internasional. Sedangkan aksesi (accession) yaitu apabila Negara yang akan mengesahkan suatu perjanjian internasional tidak turut menandatangi naskah perjanjian.Lihat juga Pasal $1 \mathrm{UU}$ No. 24 Tahun 2000 tentang Perjanjian Internasional.

${ }^{69}$ Berdasarkan pasal 10 UU No. 24 Tahun 2000 tentang Perjanjian Internasioanl disebutkan bahwa ratifikasi dengan undang-undang dapat dilakukan, manakala materi perjanjian internasional berkaitan dengan, a. Masalah politik , perdamaian, dan keamanan negara; b, Perubahan wilayah dan penetapan batas wilayah Negara Republik Indonesia ; c, Kedaulatan atau hak berdaulat Negara; d, Hak asasi manusia dan lin gkungan hidup; e, Pembentukan kaidah hukum baru ; f , Pinjaman dan atau hibah luar negeri. Lihat Pasal 10 UU No. 24 Tahun 2000.
Meskipun Indonesia telah memiliki basis hukum perlindungan hak asasi manusia yang kuat sebagaimana terumuskan dalam konstitusi, Indonesia tetap dipandang perlu untuk mengikatkan diri dengan sistem perlindungan internasional hak asasi manusia. Melalui pengikatan itu, selain menjadikan hukum internasional sebagai bagian dari hukum nasional (supreme law of the land), juga memberikan landasan legal kepada warga negaranya untuk menggunakan mekanisme perlindungan hak asasi manusia internasional, apabila ia (warga negara) merasa bahwa mekanisme domestik telah mengalami exhausted (mentok). ${ }^{70}$

Sejak tahun 1998, Indonesia telah memiliki Rencana Aksi Nasional Hak Asasi Manusia (RANHAM) untuk mengejar ketertinggalan di bidang ratifikasi tersebut. Dengan adanya RANHAM, diharapkan proses ratifikasi dapat berjalan dengan terencana. Melalui RANHAM ini, yang periode lima tahun pertamanya dimulai pada 1998-2003, telah disusun skala prioritas untuk melakukan ratifikasi terhadap instrumen-instrumen hak asasi manusia internasional. Sedangkan pada RANHAM lima tahun kedua (20042009), rencana ratifikasi diprioritaskan pada konvensi-konvensi berikut ini: (i) Konvensi untuk Penindasan Perdagangan Orang dan Eksploitasi Prostitusi Orang Lain (pada 2004); (ii) Konvensi tentang Perlindungan Hak Pekerja Migran dan Keluarganya (pada 2005); (iii) Protokol Opsional tentang Hak Anak tentang Perdagangan Anak, Pornografi Anak dan Prostitusi Anak (pada 2005); (iv) Protokol Opsional tentang Konvensi Hak Anak tentang Keterlibatan Anak dalam Konflik Bersenjata (pada 2006); (v) Konvensi tentang Pencegahan dan Penghukuman Kejahatan Genosida (pada 2007); Statuta Roma (pada 2008); dan seterusnya. Kalau rencana aksi ini berjalan, maka pada 2009

${ }^{70}$ Landasan legal ini diperkuat oleh Pasal 17 (1) UU No.39/1999 yang menyatakan "Setiap oran berhak untuk menggunakan semua upaya hukum nasional dan forum internasional atas semua pelanggaran Hak Asasi Manusia yang dijamin oleh hukum Indonesia dan hukum internasional mengenai Hak Asasi Manusia yang telah diterima oleh negara Republik Indonesia”. 
Indonesia dapat mensejajarkan diri dengan negara-negara lain yang tingkat ratifikasinya tinggi.

Sebagaimana dipaparkan diatas, bahwa disamping termuat dalam UUD Negara Republik Indonesia Tahun 1945 pasca amandemen maupun Undang-Undang Nomor 39 Tahun 1999 tentang Hak Asasi Manusia, jaminan konstitusional dan legal hak asasi manusia juga telah diatur dalam beberapa undang-undang yang merupakan hasil dari ratifikasi terhadap sejumlah konvensi internasional. Indonesia telah mengadopsi sebagian besar instrumen normatif tentang hak asasi manusia menjadi bagian dari hukum nasional. Dapat dikatakan bahwa berbagai norma hak asasi manusia itu telah dituangkan kedalam sistem hukum nasional melalui berbagai instrumen sebagai berikut:

1. Undang-Undang Nomor 29 Tahun 1999 tentang Ratifikasi Konvensi Penghapusan Segala Bentuk Diskriminasi(International Convention on The Elimination of All Forms of Racial Discrimination)

2. Undang-Undang Nomor 5 Tahun 1998 tentang Ratifikasi Konvensi Menentang Penyiksaan dan Perlakuan atau Penghukuman Lain yang Kejam, Tidak Manusiawi, atau Merendahkan Martabat Manusia(Convention Againts Torture and Other Cruel, Inhuman or Degrading Treatment or Punishment)

3. Undang-Undang Nomor 19 Tahun 1999 tentang Ratifikasi Konvensi ILO Nomor 105 tentang Penghapusan Pekerja Secara Paksa (ILOConventionNo.105Concerning The Abolition Of Forced Labour)

4. Undang-Undang Nomor 20 Tahun 1999 tentang RatifikasiKonvensiILONomor 138 tentang Usia Minimum Bagi Pekerja (ILO Convention No. 105 Concerning Minimum Age For Admission to Employment)

5. Undang-Undang Nomor 21 Tahun 1999 tentang Ratifikasi Konvensi ILO No. 11 tentang Diskriminasi dalam Pekerjaan (ILO Convention No.111 Concerning Discrimination in Respect of Employment and Occupation)
6. Undang-Undang Nomor 7 Tahun 1984 tentang Pengesahan Konvensi Mengenai Penghapusan Segala Bentuk Diskriminasi terhadap Wanita.

7. Undang-Undang Nomor 68 Tahun 1958 tentang Pengesahan Pengesahan Convention on the Political Rights of Women.

8. Undang-Undang Nomor 59 Tahun 1958 tentang Pengesahan Geneva Convention For The Amelioration of The Wounded and Sick in Armed Forces in The field.

9. Undang-Undang Nomor 59 Tahun 1958 tentang Pengesahan Geneva Convention for the Amelioration of The Condition of the wounded and Shipwrecked Members of Armed Forces at Sea, 1949.

10.Undang-Undang Nomor 59 Tahun 1958 tentang Pengesahan Geneva Convention Relative to the Treatment of Prisoners of War, 1949

11.Undang-Undang Nomor 59 Tahun 1958 tentang Geneva Convention Relative to the Protection of Civilian Peons in Time of War, 1949

12.Undang-Undang Nomor 11 Tahun 2005 tentang Pengesahan International Convenant on Economic, Social, and Cultural Rights, 1977

13.Undang-Undang Nomor 12 tahun 2005 tentang Pengesahan International Convenant Civil and Political Rights, 1966 14.Undang-Undang Nomor 6 Tahun 2006 tentang Pengesahan International Convention For The Supression of The Financing of The Terorism, 1999

15.Undang-Undang Nomor 7 Tahun 2006 tentang Pengesahan United Nation Convention Againts Corruption, 2003

16.Undang-Undang Nomor 26 Tahun 1999 tentang Pencabutan UU No. 11 Tahun 1963 tentang Tindak Pidana Subversi.

17.Undang-Undang Nomor 39 Tahun 1999 tentang Hak Asasi Manusia

18.Undang-Undang Nomor 40 Tahun 1999 tentang Pers

19.Undang-Undang Nomor 8 Tahun 1999 tentang Perlindungan Konsumen 
20.Undang-Undang Nomor 26 Tahun 2000 tentang Pengadilan Hak Asasi Manusia

21.Perpu Nomor 1 Tahun 1999 tentang Pengadilan Hak Asasi Manusia

22.Keputusan Presiden Nomor 129 Tahun 1998 tentang Remcana Aksi Nasional Hak Asasi Manusia 1998"2003

23.Keputusan Presiden Nomor 40 Tahun 2004 tentang Rencana Aksi Nasional Hak Asasi Manusia 2004"2009

24.Dan lain sebagainya.

Melihat beragam bentuk produk kebijakan yang telah dikeluarkan pemerintah berkaitan dengan hak asasi manusia, terlihat sepintas bahwa sejatinya konsep HAM sudah terumuskan secara lengkap dan sempurna. Persoalannya adalah seberapa banyak regulasi tersebut untuk dapat diimplementasikan sebagai upaya memberikan perlindungan dan jaminan konstitusional sekaligus penegakan hak-hak asasi manusia di Indonesia. Beragam kasus pelanggaran HAM baik yang terjadi sebelum reformasi maupun setelahnya, ternyata masih menyisakan banyak pertanyaan dan misteri terkait dengan proses penyelesainnya.

Para korban pelanggaran HAM berat masa lalu termasuk juga para aktifis dan mahasiswa yang menjadi korban penculikan paksa dan Tragedi Trisakti dan Semanggi 1998, hingga kini masih menunggu pemulihan hak dari pemerintah, sementara para pelaku masih berkeliaran bebas tak tersentuh hukum. Pembantaian masal 1965 yang terjadi lebih dari 40 tahun silam juga tidak pernah diperiksa secara layak di hadapan hukum. Meskipun Indonesia telah memiliki Komisi Nasional Hak Asasi Manusia (Komnas HAM) dan telah melakukan sejumlah langkah reformasi institusional pasca rezim Soeharto yang jatuh pada tahun 1998, kesulitan masih saja dialami oleh para penggiat dan pejuang hak asasi manusia di dalam negeri. Di daerahdaerah kritis seperti Papua, aktifitas hak asasi manusia adalah pekerjaan yang menempatkan nyawa sebagai taruhannya. Pada tanggal 17 Oktober 2008, Yosias Syet, seorang aktifis HAM di Papua, ditemukan tewas. Luka-luka di sekujur tubuhnya mengindikasikan bahwa dia dibunuh (laporan asian human right comission-indonesia).

Melihat fakta tersebut, tampak bahwa jaminan dan upaya perlindungan HAM di Indonesia masih dalam proses yang terus berdinamika. Kejelasan, ketegasan pemerintah untuk menyelesaikan pelanggranpelanggaran HAM yang pernah terjadi masih manjadi impian para pejuang HAM. Sehingga tak dapat dipungkiri, antara expektasi dan psimisme terus menjadi pergulatan dalam nurani kita. Meskipun sedikit putus asa dan kecewa, setidaknya masih mending upaya pengaturan dan jaminan konstitusional hak-hak asasi manusia telah mengalami kemajuan. Hasil tersebut tentunya manjadi sebuah prestasi bagi para stake holder dan para pajuangan HAM di Indonesia.

\section{KESIMPULAN}

Perlindungan hukum anak jalanan dalam konsep ham menurut UUD NRI 1945 pasca reformasi adalah yang senantiasa menjunjung tinggi dan melindungi hakhak anak jalanan sebagai manusia yang berharkat dan bermartabat. Pertama, street based, yakni model penanganan anak jalanan di tempat anak jalanan itu berasal atau tinggal kemudian para street educator datang kepada mereka berdialog mendampingi mereka bekerja, memahami dan menerima situasinya serta menempatkan diri sebagai teman. Kedua, centre based, yakni pendekatan dan penanganan anak jalanan dilembaga atau panti. Ketiga, community based yakni metode penanganan yang melibatkan seluruh potensi masyarakat terutama keluarga atau orang tua anak jalanan.

\section{DAFTAR PUSTAKA}

Assiddiqie, Jimly. (2006). Perihal Undangundang. Konstitusi Press, Jakarta.

(2007). Perihal Undang-undang di Indonesia. Sekretariat Jenderal dan Kepaniteraan Mahkamah 
Konstitusi RI. Jakarta.

Attamimi A. Hamid S., (1992). Teori Perundang-ndangan Indonesia. Pidato Pengukuhan Guru Besar pada Fakultas Hukum Universitas Indonesia, Jakarta.

. 1996. Cita Negara Persatuan Indonesia. BP-7 Pusat. Jakarta.

Budiono, A. R. (2007). Perlindungan Hukum untuk Pekerja Anak. Disertasi, Surabaya, Program Pascasarjana Universitas Airlangga.

Barda Nawawi, Arif. (1998). Beberapa Kebijakan Penegakan dan Pengembangan Hukum Pidana. PT. Citra Bakti, Bandung.

Bagong Suyanto dan Sanituti Hariadi. (2002). Krisis dan Child Abuse, Kajian Sosiologis Tentang Kasus Pelanggaran Hak Anak dan Anak-anak yang Membutuhkan Perlindungan Khusus. Penerbit Airlangga University Prees.

Boer, M. (2001). Hukum Internasional Pengertian Peranan dan Fungsi dalam Era Dinamika Global.

Bruggink, J. J. H., \& Hukum, R. T. (1996). alih bahasa Arief Sidharta. Bandung: Citra Aditya Bakti.

Endrawati, N. (2012). Perlindungan Hukum Terhadap Pekerja Anak Di Sektor Informal (Studi Kasus di Kota Kediri). Jurnal Dinamika Hukum, 12(2), 270-283.

Gosita, Arif. 1998. Masalah Perlindungan Anak. Akademindo Pressindo Jakarta.

Hartono, S. (1994). Penelitian Hukum di Indonesia pada akhir Abad ke-20. Alumni.

Irma Setyowati Sumitro. (1990). Aspek Perlindungan Hukum. Bumi Aksara. Jakarta
Isjwara, F., \& Starke, J. G. (1972). Pengantar hukum internasional. Alumni.

Lalu Husni. (2004) Pengantar Hukum Ketenagakerjaan. RajaGrafindo Persada. Jakarta.

Gultom, M. (1997). Aspek Hukum Pencatatan Kelahiran dalam Usaha Perlindungan Anak pada Kantor Catatan Sipil Kotamadya (Doctoral dissertation, Tesis, Program Pascasarjana USU, Medan).

Kusumaatmadja, M., \& Agoes, E. R. (1982). Pengantar Hukum Internasional, cet. Keempat. Binacipta. Bandung.

Maidin Gultom. 2006. Perlindugan Hukum Terhadap Anak Dalam Sistim Peradilan Anak di Indonesia. Penerbit Grafika Aditama. Bandung.

Nusantara, A. H. G. (1986). Prospek Perlindungan Anak. In Makalah: Seminar Perlindungan Hak-Hak Anak. Jakarta.

Tjandraningsih, I., Sasmito, W., Munthe, R., Sp, O., Simandjuntak, A., Tigor, A., ... \& Sudrajat, T. (1996). Dehumanisasi Anak Marjinal: berbagai Pengalaman Pemberdayaan. AKATIGA.

Taniwijaya, F. (2009). Pembinaan Anak di Lembaga Pemasyarakatan Anak dalam Rangka Perlindungan Hak Anak Pidana. Disertasi, Program Doktor Ilmu Hukum Fakulras Hukum Universitas Brawijaya Malang.

Rusmini, A. A. A. N. T. (2014). The Formulation Policy On Child Protection As Victim Of Paedophilia. Academic Research International. 5 (1). 298 .

Suradi, S. (2017). Perlindungan Anak Di Nusa Tenggara Barat. Sosio Konsepsia. 11(3), 1-17.

Sutatiek, S. (2007). Putusan Pengadilan Anak sebagai Manifestasi Perlindungan 
dan Kesejahteraan Anak di Indonesia. Disertasi, Fakultas Hukum Universitas Brawijaya.

Schachter, O. (1950). The Charter and the Constitution: The Human Rights Provisions in American Law. Vand. L. Rev., 4, 643.

Soekanto, Soerjono dan Purnadi Purbacaraka. (1993). Perihal Kaedah Hukum. Citra Adita Bakti Bandung.

. (1986). Pengantar Penelitian Hukum. UI Press. Jakarta.

-----------. (2002). Faktor-faktor yang Mempengaruhi Penegakan Hukum. Rajawali Press. Jakarta.

. dan Sri Mamudji. (1985). Penelitian Hukum Normatif Suatu Tinjauan Ringkas. Rajawali Pers. Jakarta.

Wignjosoebroto, S. (1995). Sebuah Pengantar ke arah Perbincangan tentang Pembinaan Penelitian Hukum dalam PJP II, Makalah, disampaikan dalam Seminar Akbar 50 Tahun Pembinaan Hukum Nasional dalam PJP II. BPHN. Departemen Kehakiman. Jakarta.

Wiratraman, R. H. P. (2007). Hak-Hak Konstitusional Warga Negara Setelah Amandemen UUD 1945: Konsep, Pengaturan dan Dinamika Implementasi. Jurnal Hukum Panta Rei, 1(1), 1-18. 